\title{
ボルト・ナット締結体の疲労強度に及ぼすボルト形状とピッチ差付与の影響
}

\author{
小田 和広*1, 松成 智彦*2, 王 彪*3, 野田 尚昭*4 \\ 佐野 義一 ${ }^{* 5}$, 立石 孝介*3, 薬師寺 輝敏*6，乾 湧人*3
}

\section{Effects of bolt shape and pitch difference on fatigue strength for bolted joint}

\author{
Kazuhiro ODA ${ }^{* 1}$, Tomohiko MATSUNARI ${ }^{* 2}$, Biao WANG $^{* 3}$, Nao-Aki NODA $^{* 4}$, Yoshikazu SANO*5, \\ Kosuke TATEISHI ${ }^{* 3}$, Terutoshi YAKUSHIJI ${ }^{* 6}$ and Yuto INUI ${ }^{* 3}$

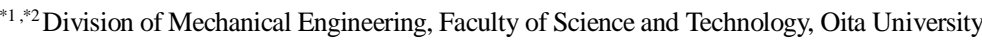 \\ 700 Dannoharu, Oita-shi, Oita 870-1192, Japan \\ ${ }^{* 3, * 4, * 5}$ Department of Mechanical Engineering, Kyushu Institute of Technology \\ 1-1 Sensui-cho, Tobata-ku, Kitakyushu-shi, Fukuoka 804-8550, Japan \\ ${ }^{* 6}$ Department of Mechanical Engineering, National Institute of Technology, Oita College \\ 1666 Maki, Oita-shi, Oita 870-0152, Japan
}

Received: 17 September 2019; Revised: 21 December 2019; Accepted: 10 March 2020

\begin{abstract}
In this study, the effect of curvature radius of the thread bottom and the pitch difference between of M16 bolt and nut on fatigue strength for bolted joint is considered experimentally. The M16 bolt-nut specimens having the two kinds of thread bottom radii and the pitch differences are prepared. The S-N curves for bolted specimens with different thread shapes are obtained by the stress-controlled fatigue test (stress ratio $\mathrm{R}>0$ ). The experimental results are compared and discussed in terms of stress analysis. The finite element method is used to make a simulation of the fatigue experiment and the mean stress and stress amplitude at each thread bottom of bolt are analyzed. It is found that the initiation and propagation of crack are changed by introducing the pitch difference of $\alpha=15 \mu \mathrm{m}$, from the crack observation on the surface of the bolt specimens after the experiment. Furthermore, the fatigue limit can be substantially improved by increasing curvature radius of thread bottom and introducing the pitch difference.
\end{abstract}

Keywords : Bolted joint, Fatigue strength, Pitch difference, Curvature radius, Finite element method

\section{1. 緒言}

ボルト・ナット締結体は，使用頻度，重要度が高い機械要素で産業界に広く普及しており，例えば，自動車 1 台に約 3000 本程度使用されているため，低価格で高い疲労強度が要求される. ボルトの破損には，ボルト自身の 疲労強度の不十分と緩みに伴う衝撃の付加に起因するものがある。これまで，ボルト・ナット締結体における疲 労強度向上に関して, 実験的研究や(Nishida et al., 1997) (平井他, 2005) (西田, 2018), 解析的研究がある (Maruyama, 1976）（Honarmandi et al., 2005）。また，通常のボルト・ナット締結体では，ねじ谷底に常に高い応力集中が生じる ため, ボルト谷底の形状を変化させて, ねじ谷底の応力緩和をした研究もなされており有限寿命が向上すること が示されている（Honarmandi et al., 2005）（西田，2018）。しかし，最も重要な疲労限度が向上するという報告は見 当たらない，著者らのこれまでの研究でも，ボルトとナット間にピッチ差を付与することで，疲労寿命および䋧

\footnotetext{
No.19-00339 [DOI:10.1299/transjsme.19-00339], J-STAGE Advance Publication date : 23 March, 2020

${ }^{* 1}$ 正員, 大分大学 理工学部（广870-1192 大分県大分市旦野原 700)

*2 大分大学大学院 工学研究科 (現 ダイハツ工業 (株))

*3 九州工業大学大学院 工学研究科（广803-0551 福岡県北九州市戸烟区仙水町 1-1)

*4 正員, フェロー, 九州工業大学大学院 工学研究院 機械知能工学系

*5 正員, 九州工業大学 工学部

*6 正員, 大分工業高等専門学校 機械工学科（广870-0152 大分県大分市牧 1666）

E-mail of corresponding author: oda-kazuhiro@ oita-u.ac.jp
} 
み止め性能の向上は得られたが，疲労限度の向上は得られていない（Chen et al., 2013, 2015）（赤石他，2013）（野 田他，2015a，2015b）。このことは，著者ら研究で得られた図 1 の結果を見ても明らかである.

そこで本論文では，ボルト・ナット締結体の疲労限度の向上を目指し，ボルト・ナット間のピッチ差の付加に 加えて, 新たにボルト㸚じ谷底の曲率半径を大きくしたボルト形状の疲労強度を実験的に明らかにするとともに, 有限要素法を用いて, 応力緩和の効果を解析的に考察する。そして, これまでに実証例が見当たらないボルト形 状の変更による疲労強度の向上を目標とする.

\section{2. 疲労試験方法}

本研究では, M16 ボルト・ナット試験片の疲労強度について検討する. 本研究で用いる M16 ボルト・ナットの 規格を表 1 に示す．本研究では，疲労限度向上のために，ボルト谷底の曲率半径を大きくした新しいボルト形状 を提案する. 図 2 にボルト締結体の概略図および図 3 にボルト・ナットのねじ部の寸法を示す. 図 2 中の番号 3 , $-2, \ldots 7,8$ はボルトの各ねじ谷底に対応寸る. 標準形状のボルト・ナット締結体のねじ底曲率は $\rho=\rho_{0}$ であり, 新 しく提案するボルト試験片の谷底曲率は $\rho=2 \rho_{0}$ である. それぞれの曲率半径増大による応力集中の低減効果の参 考值として, 切久深さと曲率半径がボルトと同形状の $60^{\circ} \mathrm{V}$ 形円周切欠きを有する丸棒の引張りにおける応力集 中係数 $\mathrm{K}_{\mathrm{t}}$ の值を図 3 に示寸. 㸚じ谷底半径を大きくすることで応力集中係数 $\mathrm{K}_{\mathrm{t}}=4.53\left(\rho=\rho_{0}\right)$ から $\mathrm{K}_{\mathrm{t}}=2.90\left(\rho=2 \rho_{0}\right)$ へと大きく減少する.

試験片として用いたボルトはクロムモリブデン鋼，ナットは焼き入れ焼き戻しされた中炭素鋼 S45Cであり， 表 2 にそれらの機械的性質を示す．また，図 4 に解析に用いたボルト・ナットの応力ひずみ線図を示す. 図 5 に は疲労試験機に装着される供試ボルト締結体の組み立て状態を示す。図 5 中では, ボルト・ナット締結部の組み 立て状態を明確にするため，他の部分よりも大きく描いている．図 5 の疲労試験方法に示すように，ここでは締 め付けは行わず，ねじ込みによってナットをボルトねじ先端部から $10 \mathrm{~mm}$ の位置に装着した後, 疲労試験を開始 する.ここで, 㱛じ込みと締め付けの違いについて, 著者らは最近, ピッチ差付きナットの締め付ける前のねじ 込み過程を FEM と実験で研究している（野田他，2019）。水じ谷底曲率の異なるボルトの最小断面部の平均断面
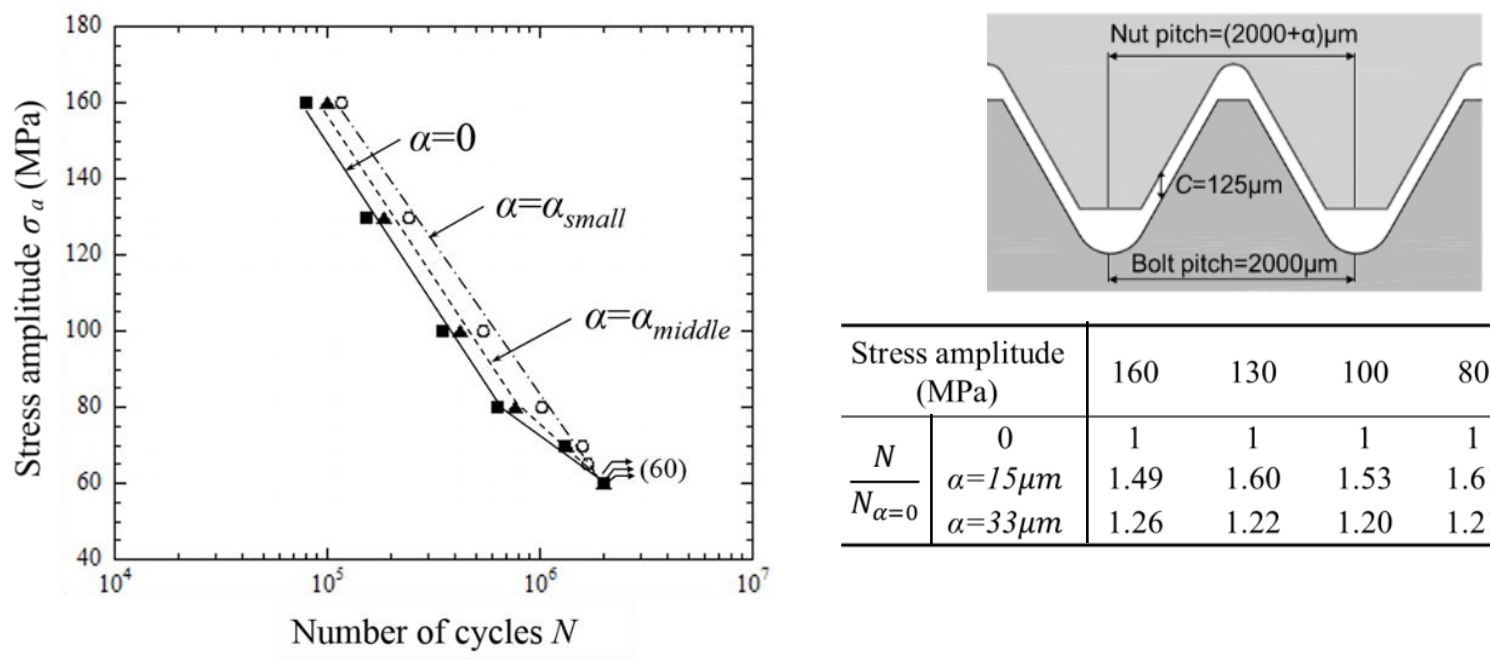

\begin{tabular}{c|c|ccccc}
\hline $\begin{array}{c}\text { Stress amplitude } \\
(\mathrm{MPa})\end{array}$ & 160 & 130 & 100 & 80 & 70 \\
\hline \multirow{2}{*}{$N$} & 0 & 1 & 1 & 1 & 1 & 1 \\
$N_{\alpha=0}$ & $\alpha=15 \mu m$ & 1.49 & 1.60 & 1.53 & 1.61 & 1.21 \\
& $\alpha=33 \mu \mathrm{m}$ & 1.26 & 1.22 & 1.20 & 1.21 & 1.02 \\
\hline
\end{tabular}

Fig. 1 S-N curves for bolt-nut joints having the pitch difference $\alpha=0,15,33 \mu$ m when $\rho=\rho_{0}$.

Table 1 JIS Standard of bolt and nut.

\begin{tabular}{c|c|c|c}
\hline \hline & $\begin{array}{c}\text { Strength } \\
\text { grade }\end{array}$ & $\begin{array}{c}\text { Yield strength } \\
(\mathrm{MPa})\end{array}$ & $\begin{array}{c}\text { Tensile strength } \\
(\mathrm{MPa})\end{array}$ \\
\hline Bolt & 8.8 & 660 & 830 \\
\hline Nut & 8 & - & - \\
\hline
\end{tabular}


積は $\mathrm{A}_{R}=141 \mathrm{~mm}^{2}$ であるので, 平均応力は $\sigma_{m}=213 \mathrm{MPa}$ とした．この平均荷重を負荷することでボルト軸力を模 擬している. 負荷条件は, 平均応力一定とした片振り引張疲労であり, $98 \mathrm{kN}$ (10 tonf) サーボ疲労試験機を用い, 周波数を 5 または $10 \mathrm{~Hz}$ とした. 表 3 に本試験で設定した負荷条件を示す. S-N 曲線は, 繰返し数 $2 \times 10^{6}$ 回をもっ て疲労限とし， 5 レベルの応力振幅の実験結果から求めた.

図 1 に示寸ように，前報（野田他，2015a, 2015b）においては $\alpha=15,30 \mu \mathrm{m}$ のピッチ差を付与した疲労試験を実 施した. その結果， $\alpha=15 \mu \mathrm{m}$ のピッチ差が疲労強度向上に対する影響が顕著であったため, 本研究では, ピッチ差 $\alpha=0$ と $15 \mu \mathrm{m}$ に対して比較を行った. また, ボルト谷底の大曲率化による疲労強度への影響およびピッチ差付与 の効果とそのメカニズムについて考察する.

\section{3. 疲労試験結果および破面観察}

ボルト・ナット締結体の疲労限度向上を目指し，前述したようにボルト谷底曲率を大きくしたボルト試験片を 製作し, 疲労試験を実施した。標準形ボルトの試験結果と比較して, 疲労強度に及ぼすボルト谷底の曲率半径の 影響を検討した。

\section{$3 \cdot 1$ ボルト谷底曲率が疲労強度に及ほす影響}

図 6 にねじ谷底半径 $\rho=\rho_{0}$ と $2 \rho_{0}$ のボルト締結体の疲労試験によって得られた S-N 曲線を示す．試験片のピッチ 差は全て $\alpha=0 \mu \mathrm{m}$ である. 図 6 から, 㸚じ谷底半径を大きくすることで疲労寿命が 2 倍以上に向上し, 疲労限度は 通常のボルト・ナット締結体より約 30\%向上し, $80 \mathrm{MPa}$ となった.

西田（2018）は，㸚じ谷底径 $\phi 25 \mathrm{~mm}$ でねじ谷底半径 $\rho=0.30 \mathrm{~mm}, 0.5 \mathrm{~mm}$ および $0.7 \mathrm{~mm} の 3$ 種類のボルト（ねじ 外径およびねじ山高さはほぼ等しい）を用いて疲労試験を行い，ねじ谷底半径の影響について検討している．そ して，実験の範囲では，ねじ谷底半径の疲労特性への影響はほとんど認められず，㸚じ形状は総合的に評価すべ きと結論している，本実験では，ねじ谷底半径の増加は疲労強度向上に寄与寸る結果となった．詳細は 4 章の有 限要素解析結果に譲るが，ボルトねじ谷底の応力集中緩和が，疲労限度向上の主要因と考えられる．また，本実 験で使用した $2 \rho_{0}$ のボル卜試験片では㸚じ山高さが低くなっているため, これも応力集中の低減に貢献している

（野田他，2015b）。その相乗効果で，疲労強度が向上したものと考えられる.

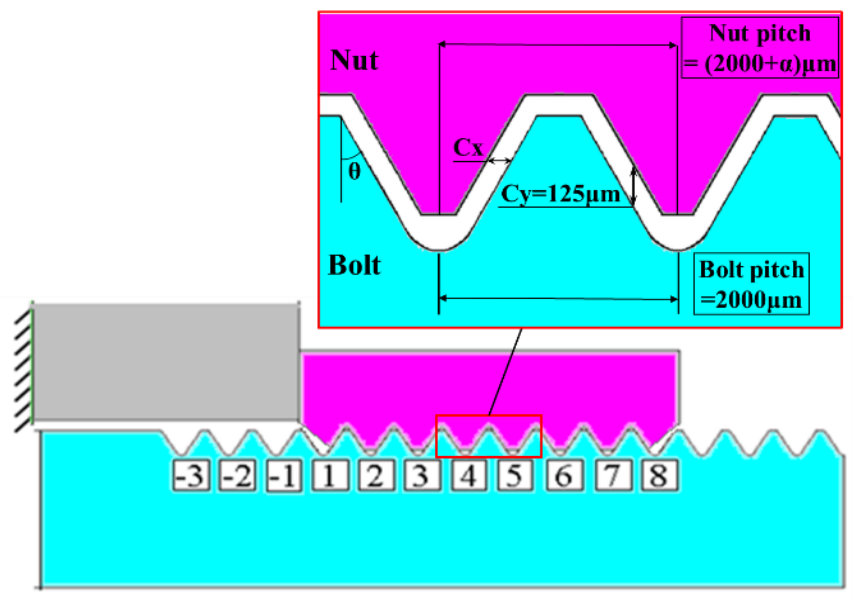

Fig.2 Schematic view of bolted joint.

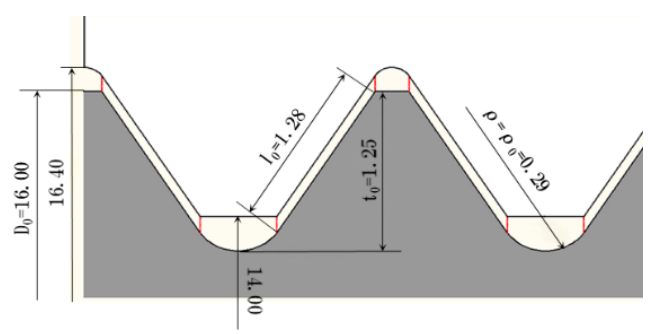

(a) $\rho=\rho_{0}\left(K_{t}=4.53\right)$

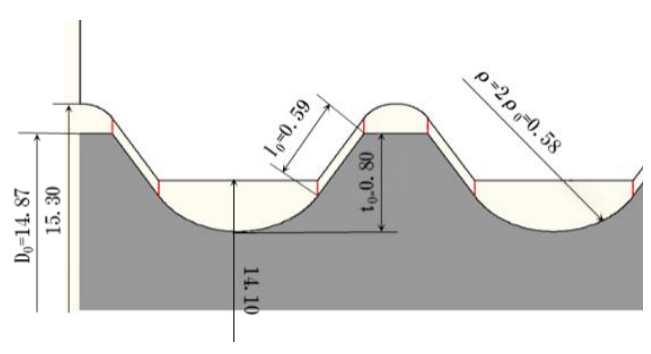

(b) $\rho=2 \rho_{0}\left(K_{l}=2.90\right)$

Fig. 3 Two types of bolt specimens with different thread shapes. 
Oda, Matsunari, Wang, Noda, Sano, Tateishi, Yakushiji and Inui, Transactions of the JSME (in Japanese), Vol.86, No.884 (2020)

Table 2 Material properties of bolt and nut.

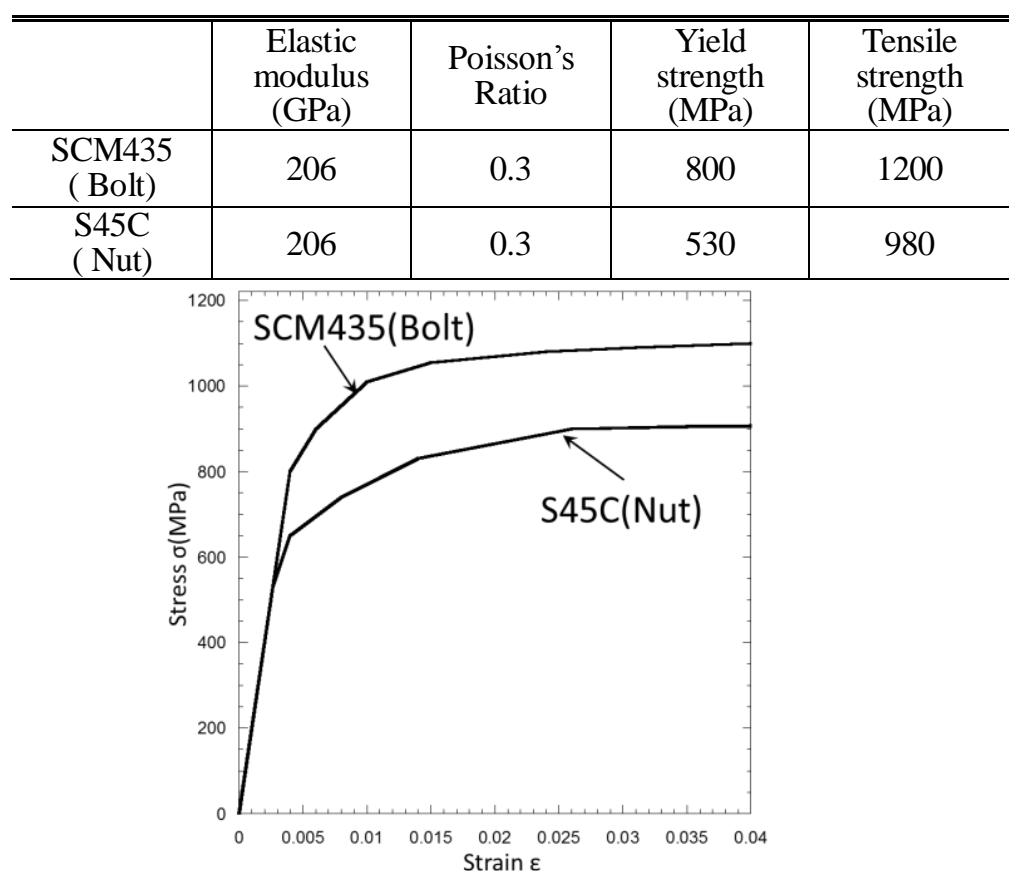

Fig. 4 Stress-strain relation for SCM435 and S45C.

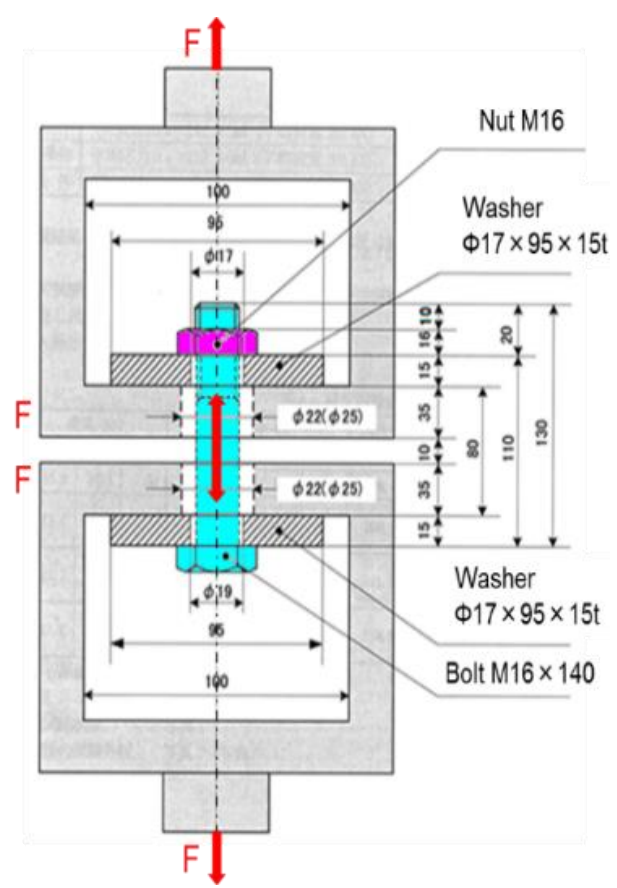

Fig. 5 Schematic illustration of fatigue test.

Table 3 Experimental conditions.

\begin{tabular}{|c|c|c|c|c|}
\hline \multicolumn{2}{|c|}{ Load $(\mathrm{kN})$} & \multicolumn{2}{|c|}{ Stress $(\mathrm{MPa})^{*}$} & \multirow{2}{*}{$\begin{array}{l}\text { Stress ratio } R \\
R=\frac{\sigma_{m}-\sigma_{a}}{\sigma_{m}+\sigma_{a}}\end{array}$} \\
\hline Mean load & Load amplitude & $\begin{array}{c}\text { Mean stress } \\
\sigma_{m}\end{array}$ & $\begin{array}{l}\text { Stress amplitude } \\
\qquad \sigma_{a}\end{array}$ & \\
\hline 30 & 22.6 & 213 & 160 & 0.14 \\
\hline 30 & 18.3 & 213 & 130 & 0.24 \\
\hline 30 & 14.1 & 213 & 100 & 0.36 \\
\hline 30 & 11.3 & 213 & 80 & 0.45 \\
\hline 30 & 8.5 & 213 & 60 & 0.56 \\
\hline
\end{tabular}

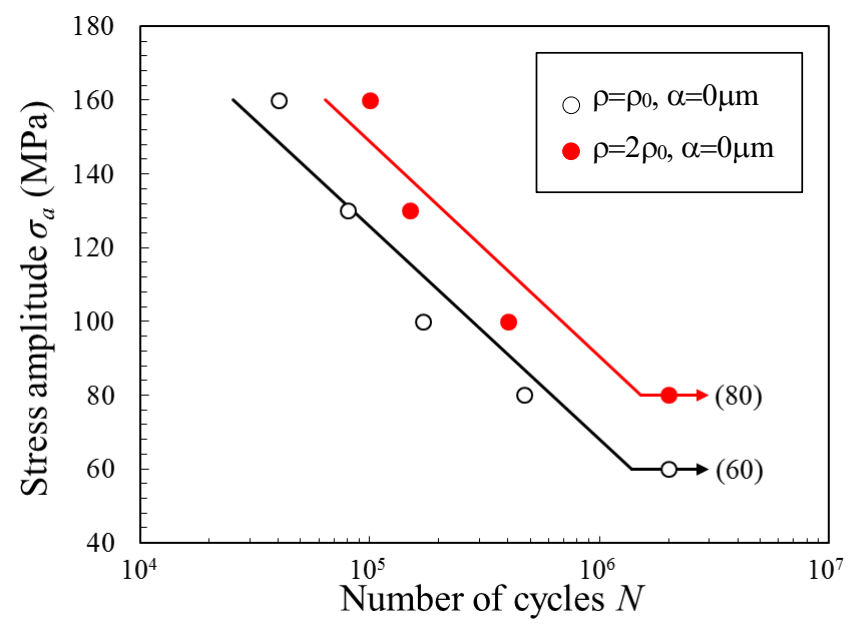

Fig. 6 S-N curves for bolted joints with different thread bottom radius when $\alpha=0 \mu \mathrm{m}$. The fatigue life of newly formed bolts is more than double that of standard bolt specimen. In addition, the fatigue limit is about $30 \%$ higher than normal bolt and nut joints. 


\section{$3 \cdot 2$ 大曲率を有する新形状ボルトへのピッチ差付与の影響}

ボルトねじ谷底の曲率半径を大きくすることで疲労限度の向上が見られた．さらにピッチ差を付与した新形状 ボルト締結体における疲労寿命と疲労限度について検討した。

図 7 にピッチ差 $\alpha=15 \mu \mathrm{m}$ の場合の新形状ボルト・ナット締結体の S-N 曲線を示す. ナットにピッチ差 $\alpha=15 \mu \mathrm{m}$ を付与した場合， $\rho=2 \rho_{0}$ の新形状ボルト締結体の疲労寿命はピッチ差 $\alpha=0$ の場合よりさらに改善し，疲労限度は $100 \mathrm{MPa}$ と $25 \%$ 向上した. 表 5 には有限寿命領域における疲労寿命を $\rho=\rho_{0}, \alpha=0 \mu \mathrm{m}$ 基準にして比較して示す. 表 5 から，ボルトねじ谷底半径の大曲率化およびピッチ差を有するボルト・ナット締結体 $\left(\rho=2 \rho_{0}, \alpha=15 \mu \mathrm{m}\right)$ で は, 標準形の場合 $\left(\rho=\rho_{0}, \alpha=0\right)$ より疲労寿命および疲労強度が約 $70 \%$ 向上し, 大幅に改善されることがわかる.

\section{$3 \cdot 3$ き裂進展状況の観察}

図 8 に疲労試験後のボルトを外周表面から観察したき裂の分布状況を示す. 図 8 （a），（b）から，ピッチ差 $\alpha=0$ ではねじ谷底 No.1〜No.3 のみでき裂が観察され，荷重分担が No.1 付近に集中していることがわかる. 図 8 (b) の $\rho=2 \rho_{0}$ でき裂発生箇所が No. 3 まで広がっているのは，ボル卜谷底形状を変えたことにより，若干接触状態が変 化したためであると考えられる，一方，図 8 (c)，（d）から，ピッチ差 $\alpha=15 \mu \mathrm{m}$ では No.2〜No.7 間にき裂が発生 している.このように，標準のボルト締結体 $(\alpha=0 \mu \mathrm{m})$ ではNo.1 またはNo.2のねじ谷底にき裂が発生し最終的 な破断が起こる．しかし，ピッチ差を付与したボルト締結体 $(\alpha=15 \mu \mathrm{m})$ では No.5または No.6のねじ谷底でき 裂が発生し，き裂はそのままボルト谷に沿って連続的に進展していない. No.6 ねじ谷底付近から No.1 谷底にか けて断続的にき裂が発生しており，最終的にNo.1 付近で破断していることが分かる．また，図 $8(\mathrm{~d})$ の $\rho=2 \rho_{0}$ では
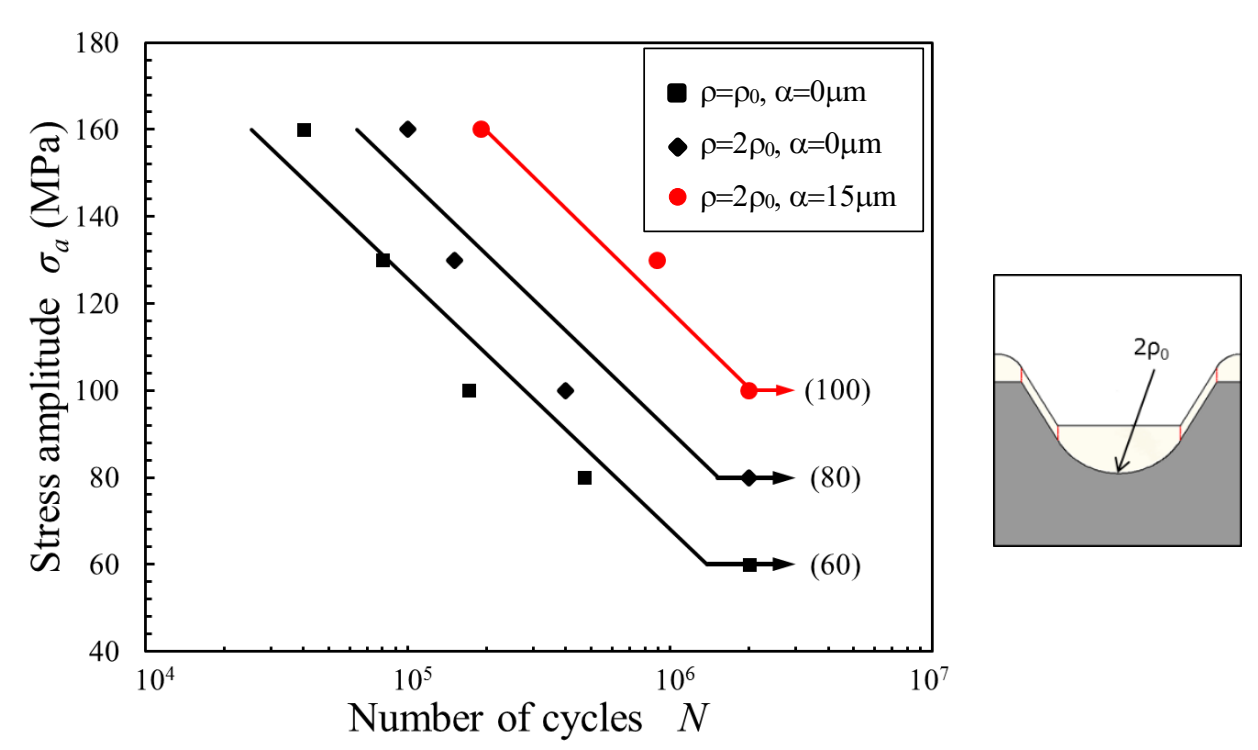

Fig. 7 S-N curves for bolted joints with different thread bottoms when the pitch difference $\alpha=15 \mu \mathrm{m}$. By applying a pitch difference of $\alpha=15 \mu \mathrm{m}$, the fatigue limit of the new shape bolt with the thread radius of $2 \rho_{0}$ is substantially improved to $100 \mathrm{MPa}$.

Table 5 Enhancement ratio of the fatigue life.

\begin{tabular}{c|c|c|c|c|c}
\hline \hline \multirow{2}{*}{$\begin{array}{c}\text { Thread bottom } \\
\text { radius }(\alpha=0 \mu \mathrm{m})\end{array}$} & 160 & 130 & 100 & 80 & 60 \\
\cline { 2 - 6 } & 1 & 1 & 1 & 1 & 1 \\
\hline$\rho=\rho_{0}(\alpha=0 \mu \mathrm{m})$ & 2.50 & 1.88 & 2.35 & 4.26 & \\
\hline$\rho=2 \rho_{0}(\alpha=0 \mu \mathrm{m})$ & 2.62 & 3.21 & 3.12 & 2.18 & 1 \\
\hline$\rho=\rho_{0}(\alpha=15 \mu \mathrm{m})$ & 4.24 & 11.75 & 11.64 & & \\
\hline$\rho=2 \rho_{0}(\alpha=15 \mu \mathrm{m})$ & & & & & \\
\hline
\end{tabular}




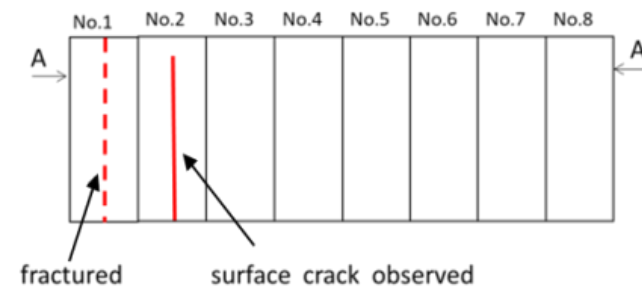

(a) $\rho=\rho_{0}, \alpha=0 \mu \mathrm{m} \quad\left(\sigma_{a}=100 \mathrm{MPa}\right)$

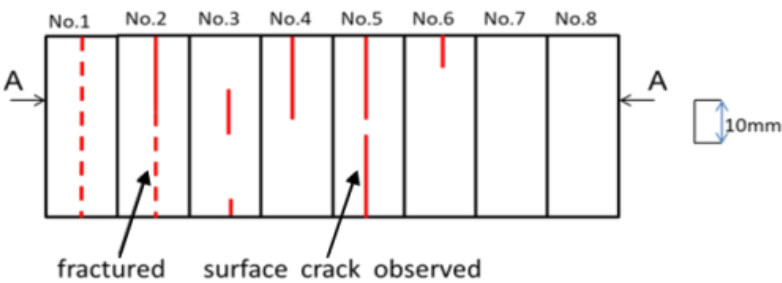

(c) $\rho=\rho_{0}, \alpha=15 \mu \mathrm{m}\left(\sigma_{a}=100 \mathrm{MPa}\right)$

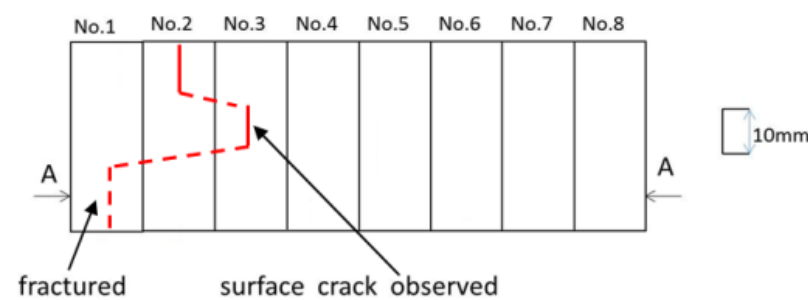

(b) $\rho=2 \rho_{0}, \alpha=0 \mu \mathrm{m}\left(\sigma_{a}=130 \mathrm{MPa}\right)$

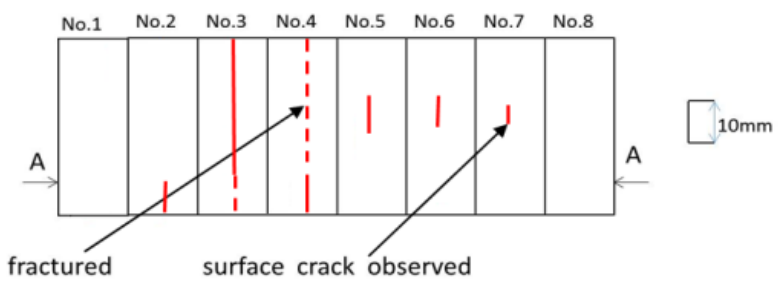

(d) $\rho=2 \rho_{0}, \alpha=15 \mu \mathrm{m}\left(\sigma_{a}=130 \mathrm{MPa}\right)$.

Fig. 8 Crack configuration observed from surface of the fractured specimens. For the bolted joints with the normal pitch $\alpha=0$, the cracks occur at No.1 thread or No.2 thread and cause final fracture. On the other hand, for the bolted joints with the pitch difference $\alpha=15 \mu \mathrm{m}$, the cracks occur intermittently between at No.6 and No.1 thread, and finally fracture happen nearby No.1 thread.

破断箇所が No.4 谷底までシフトしており，これも疲労寿命の向上に資しているものと考えられる.この理由につ いては，ピッチ差の付与によってボルトとナットの接触状態が変化し，それぞれのねじ山の荷重分担が変わるた めである（Chen et al.，2013, 2015）（赤石他，2013）（野田他，2015b）.

以上のことから，適切なピッチ差とねじ谷底の形状を導入することにより，ボルト・ナット締結体の疲労寿命 を改善できると結論付けられる.

\section{4. ボルトねじ谷底の応力状態}

\section{4-1 解析モデルおよび解析条件}

ボルトねじ谷底の応力解析には，前報（野田他，2015b）と同様に軸対称 6 山モデルを用いた. FEM 解析に用 いた軸対称モデルを図 9 に示す。困 5 に示すように，疲労試験中はボルトの頭部が下側ワッシャーの下側，ナッ

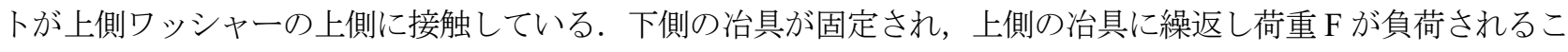
とにより，ボルト・ナット締結体に引張り側の繰返し荷重 $\mathrm{F}$ が作用する $\left(\right.$ 片振り，応力比 $\left.\sigma_{\min } / \sigma_{\max }>0\right)$. ナットに 嵌合するボルトねじの応力解析には，被締結物とナットを含む範囲を対象にモデル化すれば良い，従って，図 9 の FEM モデルでは，ワッシャー部（被締結物）を固定し，ボルトの頭部側（左側）に繰返し荷重 F を作用させ る. 解析コードは FEM コード MSC.Marc/Mentat 2012 であり，4節点の軸対称要素を採用し，最小要素サイズは ボルトねじ谷底付近で $0.015 \mathrm{~mm} \times 0.01 \mathrm{~mm}$ である. 解析モデルには，ボルト・ナット締結体の実験配置に従い， 異なるピッチとねじ谷底半径（ $\alpha=0,15 \mu \mathrm{m}$ おび $\left.\rho=\rho_{0}, 2 \rho_{0}\right)$ を有する. また，表 2 および図 4 に示すボルト・ ナットの応力ひずみ線図を適用し，FEM モデルの弾塑性解析は実験と同じ負荷条件で実施する. 被締結物のボル 卜頭部側の面を固定し，ボルト頭部に軸力 $F=30 \pm 14.1 \mathrm{kN}$ を与える. 荷重振幅 $F_{a}=14.1 \mathrm{kN}$ は，ボルトの最小断面 における公称応力振幅 $\sigma_{a}=100 \mathrm{MPa}$ に対応する. ボルトとナット間の摩擦係数は 0.3 とた. 
Oda, Matsunari, Wang, Noda, Sano, Tateishi, Yakushiji and Inui,

Transactions of the JSME (in Japanese), Vol.86, No.884 (2020)

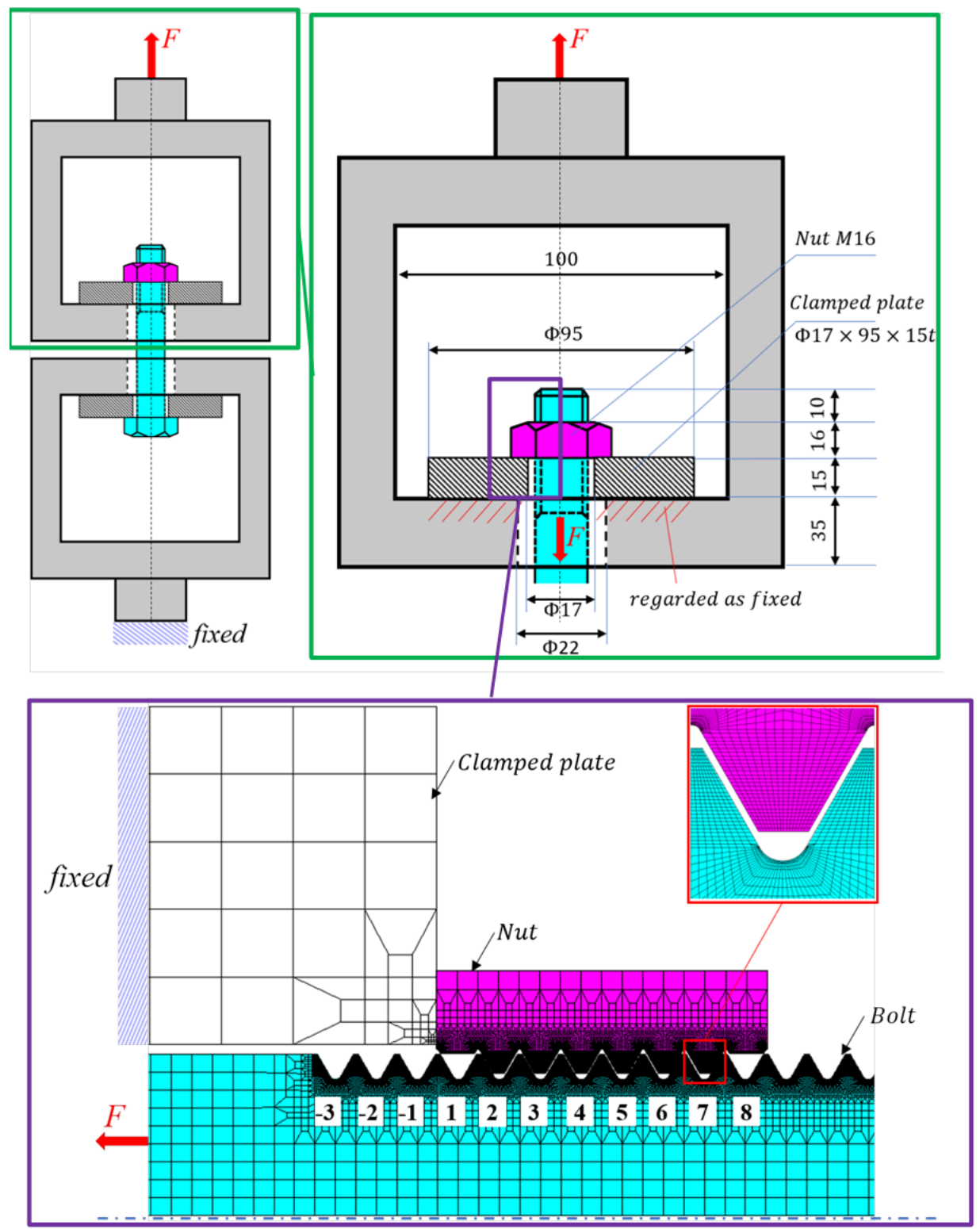

Fig. 9 Axisymmetric FEM model considering incomplete threads at both ends of nut in fatigue test of Fig. 5.

\section{$4 \cdot 2$ ボルトねじ谷底の応力振幅}

図 10 に最大, 最小荷重時の各ボルト放じ谷底に生じる最大応力振幅位置での最大応力と最小応力を示寸. 黒い 線は標準形状 $\left(\rho=\rho_{0}\right)$ のボルトねじ谷底の值であり，赤い線は新形状 $\left(\rho=2 \rho_{0}\right)$ のボルトねじ谷底の值を示してい る. 図 10(a)から, ピッチ差なしのボルト締結体 $(\alpha=0 \mu \mathrm{m})$ では No.2 のねじ谷底に最大応力振幅が発生している. ねじ谷底曲率を大きく寸ることにより $\left(\rho=2 \rho_{0}\right)$, ほとんどのねじ底で最大応力の減少が見られる. このことは, 曲率を $2 \rho_{0}$ とした新形状ボルト（ピッチ差なし）の疲労強度が上昇した図 6 の実験結果と符合している. 一方, ピッチ差 $\alpha=15 \mu \mathrm{m}$ を導入すると No. 2 のねじ谷底の応力が減少し, No.6 で最大応力振幅が, No. 7 で最大応力が生 じる. ピッチ差を付与した場合でも, 新形状ボルト $\left(\rho=2 \rho_{0}\right)$ のほとんどボルト谷底で最大応力が減少する結果が 得られた. しかしながら, 図 3 に示したボルト形状の変更によって引張荷重下における切欠きの応力集中係数 $K_{t}$ の減少割合ほど $\sigma_{\max }$ は減少しておらず， $\sigma_{\min }$ は $\rho$ が変わってもあまり変化していない，これはボル卜締結体では 単純に応力集中係数のみで衩じ谷底の応力分布が決まるのではく, ナットとの接触状態にも大きく影響するため と考えられる. 
図 11 は解析によって得られた応力值を用いて作成した耐久線図である.ここで, 縦軸は応力振幅 $\sigma_{a}=\left(\sigma_{\max }-\right.$ $\left.\sigma_{\min }\right) / 2$, 横軸は平均応力 $\sigma_{m}=\left(\sigma_{\max }+\sigma_{\min }\right) / 2$ を示す.この線図でボルト各ねじ谷底における最大応力を平滑材 の耐久線と対比したもので，相対的な安全性をみたものである. 図 11(a), (b)において，㸚じ谷底曲率を大きくす ることにより，危険度が高い敞じ谷底が，相対的に安全側へ移動した。また，図 11(a)より，ピッチ差なしの場合 はNo.1〜3の谷底が相対的に危険であり, 図 11(b)より, ピッチ差付与の場合は, No.5 7 の谷底が相対的な危険 度が高い。これらの解析結果は，疲労試験によるボルトの破面観察結果とよく一致している．しかしながら，耐 久線図に対する相対的な安全性が，実験結果により得られたピッチ差の有効性とよく整合しているとは言えない 部分があり, 今後の改善点として残る.

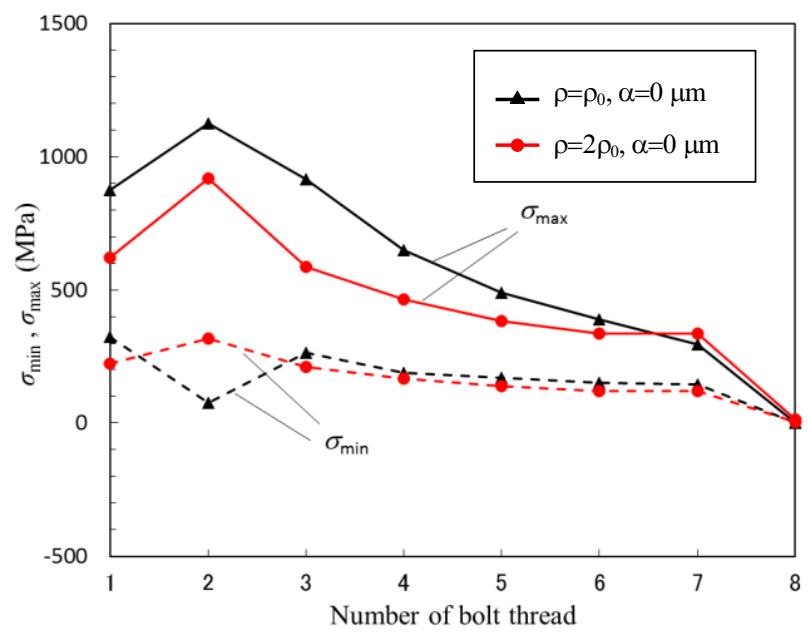

(a) $\rho=\rho_{0}, 2 \rho_{0}$ when $\alpha=0 \mu \mathrm{m}$

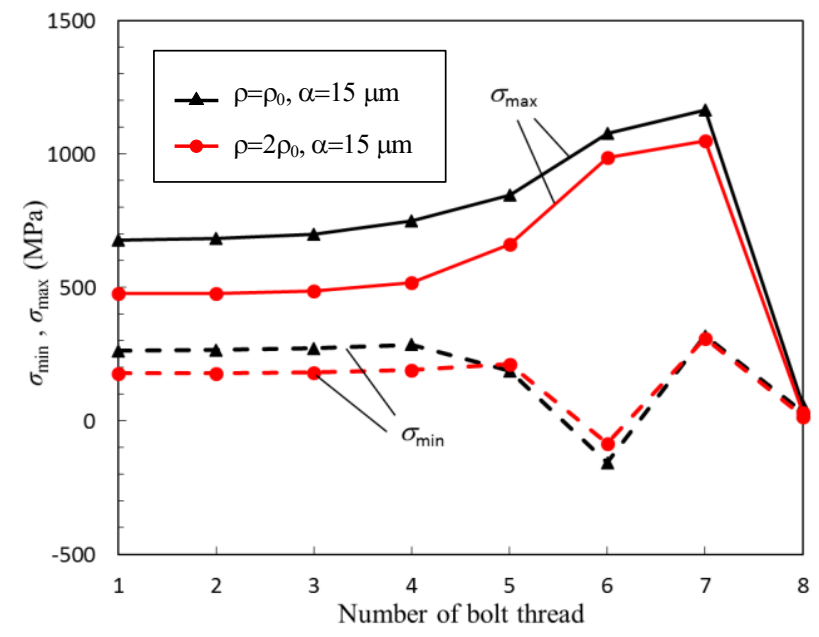

(b) $\rho=\rho_{0}, 2 \rho_{0}$ when $\alpha=15 \mu \mathrm{m}$

Fig. 10 Maximum stress $\sigma_{\max }$ and minimum stress $\sigma_{\min }$ at each bolt thread when $F_{a}=14.1 \mathrm{kN}, \sigma_{m}=213 \mathrm{MPa}, \sigma_{a}=100 \mathrm{MPa}$. By increasing the thread bottom radius of the bolt, the maximum stress decreases clearly at each thread bottom. When the pitch difference of $\alpha=15 \mu \mathrm{m}$ is introduced, the maximum stress amplitude occurs at No.6 thread instead of No.2 thread.

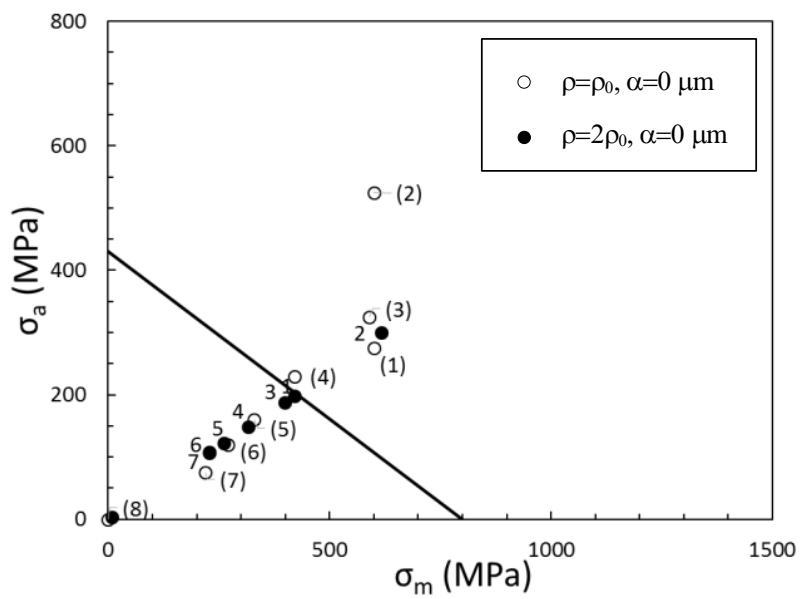

(a) $\rho=\rho_{0}, 2 \rho_{0}$ when $\alpha=0 \mu \mathrm{m}$

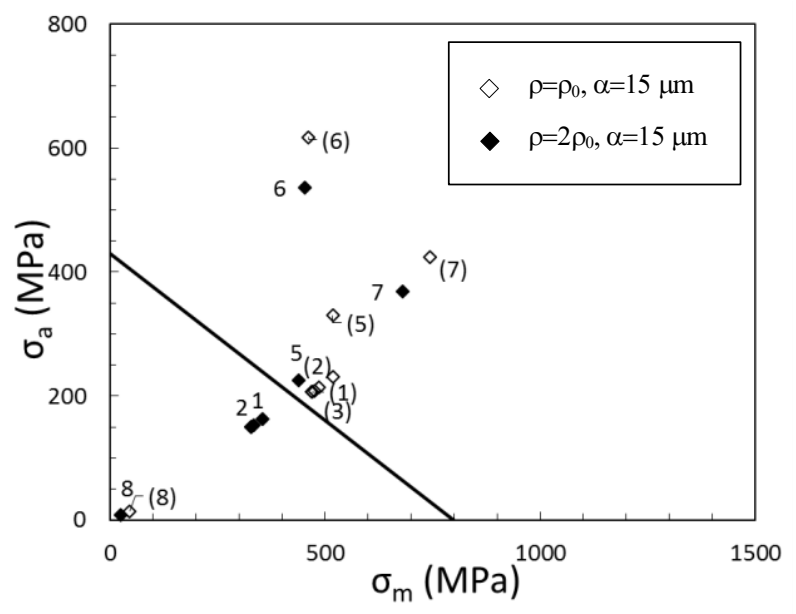

(b) $\rho=\rho_{0}, 2 \rho_{0}$ when $\alpha=15 \mu \mathrm{m}$

Fig. 11 Endurance limit diagram when $F_{a}=14.1 \mathrm{kN}, \sigma_{m}=213 \mathrm{MPa}, \sigma_{a}=100 \mathrm{MPa}$. By increasing the thread bottom radius of the bolt, the stress state of the thread with a higher risk has relatively moved to the safety side. 
Oda, Matsunari, Wang, Noda, Sano, Tateishi, Yakushiji and Inui, Transactions of the JSME (in Japanese), Vol.86, No.884 (2020)

\section{5. 結 言}

本研究では, 異なるピッチ差を有するボルト・ナット締結体において, ねじ谷底半径を変えて疲労試験を行い, 併せて FEM 解析を行った．㸚じ形状変更による疲労限度の向上を著者らが初めて実証した．得られた結果をま とめると以下のようになる.

（1）ボルト谷底の曲率半径を 2 倍に大きくすることで, 規格によるボルト・ナット締結体と比較して, 疲労限度 は約 30\%向上した.

（2）曲率を大きくし，加えてピッチ差を付与した結果，ピッチ差の無い場合と比較し，疲労限度はさらに $25 \%$ 向 上した，通常のナットと比較すると，約 70\%向上し，大幅に改善された.

（3）FEM 解析では，ピッチ差と曲率半径の効果により，危険度が高い衩じ谷が相対的に安全側へ移動した。ま た，ねじ山の相対的な危険度の高さは，疲労試験によるボルトの破面観察結果とよく一致した．しかし，相対的 な安全性が，実験結果によるピッチ差の有効性とよく整合しているとは言えない部分がある.

本研究では, 疲労限度の向上を初めて実験的に実証したが，ピッチ差による疲労限度向上の解析的検証に関し ては，今後の研究課題とする.

\section{文献}

赤石雄一郎，陳金金，于洋，玉崎英俊，野田尚昭，佐野義一，高瀬康，異なるピッチを有するボルト・ナットの組 合せによる疲労寿命向上とクリアランスの影響，自動車技術会論文集，Vol.4, No.44(2013), pp.1111-1117.

Chen, X., Noda, N.-A., Akaishi, Y., Sano, Y. and Takase, Y., Effect of pitch difference on anti-loosing performance and fatigue strength for high strength bolts and nuts, 13th International Conference on Fracture (2013), 10988-43072.

Chen, X., Noda, N.-A., Magd, A.-W., Akaishi, Y., Sano, Y., Takase, Y. and Gusztav, F., Fatigue failure analysis for bolt-nut connections having slight pitch differences using experimental and finite element methods, Acta Polytechnica Humgaria, Vol.12, No.8 (2015), pp.61-79.

平井敬二, 宇野暢芳，超高強度ボルトの疲労強度に関寸る研究，日本建築学構造系論文集，Vol.70, No.595 (2005), pp.117-122.

Honarmandi, P., Zu, J. W. and Behdinan, K., Elasto-Plastic Fatigue Life Improvement of Bolted Joints and Introducing FBI Method, Mechanics Based Design of Structures and Machines, Vol. 33, No. 3 (2005), pp. 311-330.

Maruyama, K., Stress analysis of a bolt-nut joint by the finite element method and the copper-electroplating method (3rd report, Influence of pitch error or flank angle error), Bulletin of JSME, Vol.19, No.130 (1976), pp.360-368.

Nishida, S.-I., Urashima, C. and Tamasaki, H., A new method for fatigue life improvement of screws, European Structural Integrity Society, No.22 (1997), pp.215-225.

西田新一，站じの破損と防止対策（6）ボルトの疲労強度向上策一前篇，金属，Vol.88, No.2 (2018), pp.141-148.

Noda, N.-A., Chen, X., Sano, Y., Wahab, M.A., Maruyama, H., Fujisawa, R. and Takase, Y., Effect of pitch difference between the bolt-nut connections upon the anti-loosening performance and fatigue life, Materials \& Design, Vol.96 (2016), pp.476489 .

野田尚昭, 劉溪, 佐野義一, 久保周太郎, 黄雲霆, 立石孝介, 高瀬康, ピッチ差を有するボルト・ナット締結体の䃿 じ込み過程の 3 次元有限要素法解析, 日本機械学会論文集, Vol.85, No.876 (2019), DOI:10.1299/transjsme.1900149.

野田尚昭，野間俊介，斎藤金次郎，名川政人，湯本淳，肖陽，新型アウターキャップ式ナットの応力集中緩和効 果と緩み止女効果，日本機械学会論文集 A 編，Vol.72, No.721 (2006), pp.1318-1325.

野田尚昭，佐野義一，高瀬康，陳金金，丸山光，王罣，藤澤良太，異なるピッチ差によって疲労寿命を向上させた ボルト・ナットの締結体における緩み止め性能の研究，自動車技術会論文集，Vol.46, No.1 (2015a), pp.121-126.

野田尚昭, 佐野義一, 陳金金, 丸山光, 王寰, 藤澤良太, 高瀬康, ボルトナナト締結体の疲労強度に及ぼすピッチ 差の影響とその解析モデルの提案，日本機械学会論文集，Vol. 81, No. 831 (2015b), DOI:10.1299/transjsme.1500240.

Noda, N.-A., Xiao, Y. and Kuhara, M., The reduction of stress concentration by taping threads, Journal of Solid Mechanics and Materials Engineering, Vol.5, No.8 (2011), pp.397-408. 


\section{References}

Akaishi, Y., Xin, C., Yang, Y., Tamasaki, H., Noda, N.-A., Sano, Y. and Takase, Y., Fatigue strength analysis for bolts and nuts which have slightly different pitches considering clearance, Paper Collection of Automotive Technology Society, Vol.4 No.44(2013), pp.1111-1117 (in Japanese).

Chen, X., Noda, N.-A., Akaishi, Y., Sano, Y. and Takase, Y., Effect of pitch difference on antiloosing performance and fatigue strength for high strength bolts and nuts, 13th International Conference on Fracture (2013), 10988-43072.

Chen, X., Noda, N.-A., Magd, A.-W., Akaishi, Y., Sano, Y., Takase, Y. and Gusztav, F., Fatigue failure analysis for bolt-nut connections having slight pitch differences using experimental and finite element methods, Acta Polytechnica Hungarica, Vol.12, No.8 (2015), pp.61-79.

Hirai, K. and Uno, N., Fatigue strength of super high strength bolt, Journal of Structural Engineering, Vol.70, No.595 (2005), pp.117-122.

Honarmandi, P., Zu, J. W. and Behdinan, K., Elasto-Plastic Fatigue Life Improvement of Bolted Joints and Introducing FBI Method, Mechanics Based Design of Structures and Machines, Vol. 33, No. 3 (2005), pp. 311-330.

Maruyama, K., Stress analysis of a bolt-nut joint by the finite element method and the copper-electroplating method (3rd report, Influence of pitch error or flank angle error), Bulletin of JSME, Vol.19, No.130 (1976), pp.360-368.

Nishida, S.-I., A new method for fatigue life improvement of screws, European Structural Integrity Society, No.22 (1997), pp.215-225.

Nishida, S.-I., Failure of screws and its prevention measures (6) Bolt fatigue strength improvement measures-Part 1, KINZOKU (Materials Science \& Technology), Vol.88, No.2 (2018), pp.141-148 (in Japanese).

Noda, N.-A., Chen, X., Sano, Y., Wahab, M.A., Maruyama, H., Fujisawa, R. and Takase, Y., Effect of pitch difference between the bolt-nut connections upon the anti-loosening performance and fatigue life, Materials \& Design, Vol.96 (2016), pp.476489.

Noda, N.-A., Liu, X., Sano, Y., Kubo, S., Huang, Y., Tateishi, K. and Takase, Y., Three-dimensional finite element analysis for prevailing torque in the screwing process of bolt and nut connections with pitch difference, Transactions of the JSME (in Japanese), Vol.85, No.876 (2019), DOI:10.1299/transjsme.19-00149.

Noda, N.-A., Noma, S., Saito, K., Nagawa, M., Yumoto, A. and Xiao, Y., Stress reduction effect and anti-loosening performance of outer cap nut by finite element method, Transactions of the Japan Society of Mechanical Engineers, Series A, Vol.72, No.721 (2006), pp.1318-1325 (in Japanese).

Noda, N.-A., Sano, Y., Takase, Y., Xin, C., Maruyama, H., Huan, W. and Fujisawa, R., Anti-loosing performance of special bolts and nuts having enhanced fatigue life by introducing pitch difference, Paper Collection of Automotive Technology Society, Vol.46, No.1 (2015a), pp.121-126 (in Japanese).

Noda, N.-A., Sano, Y., Xin, C., Maruyama, H., Huan, W., Fujisawa, R. and Takase, Y., Fatigue strength for bolts and nuts having slight pitch difference considering incomplete threads of nut, Transactions of the JSME (in Japanese), Vol. 81, No. 831 (2015b), DOI:10.1299/transjsme.15-00240.

Noda, N.-A., Xiao, Y. and Kuhara, M., The reduction of stress concentration by tapering threads, Journal of Solid Mechanics and Materials Engineering, Vol.5, No.8 (2011), pp.397-408. 